\title{
Samarbeid og lærerprofesjonalitet
}

\author{
(Collaboration and teacher professionalism) \\ Stein Rafoss \& Hilde Witsø \\ Universitetet i Agder, Norge (hilde.witso@uia.no)
}

\begin{abstract}
This article is about the importance of collaboration in the development of teacher professionalism, and we have asked the research question: How can group collaboration between vocational education and training (VET) students contribute to the development of their teacher professionalism? The data basis is interviews with ten VET students in practical pedagogical education for vocational teachers that we conducted in the winter of 2020. In addition, we studied all internship documents that the ten students produced during the internship period. The students are in practical training at their own school with their own students and collaborate with each other to strengthen their own teacher role. We have applied Dale's $(1989,1993,2001)$ theory of teacher professionalism. To analyse collaboration, we used the theories of Hegel (1999), Honneth $(2008,2009)$, Barth (1994) and De Hei et al. (2018). We found that this internship made it possible for students to talk and reflect on didactic questions related to Dale's three areas of expertise.
\end{abstract}

Keywords: teacher professionalism, collaboration, didactic competence, practical pedagogical education for vocational teachers (PPU-Y) collaborative learning, learning in the workplace 


\section{Innledning}

I denne artikkelen redegjør vi for et forskningsprosjekt vi gjennomførte vinteren 2020 med studenter ved praktisk-pedagogisk utdanning for yrkesfag (PPU-Y). Disse studentene har praksis på egen skole med egne elever. Artikkelen handler om samarbeidets betydning i utviklingen av egen lærerprofesjonalitet, og vi stilte dette forskningsspørsmålet: Hvordan kan gruppesamarbeid mellom yrkesfaglærerstudenter bidra til å utvikle deres lærerprofesjonalitet? Dette er et stort og omfattende spørsmål. Vi ønsker å forstå hvordan det må legges til rette for at yrkesfaglærerstudenter skal få anledning til å lære samarbeidets betydning i rollen som yrkesfaglærer.

Forskningsspørsmålet inneholder to sentrale teoretiske begreper; lærerprofesjonalitet og samarbeid. For å kunne svare på forskningsspørsmålet må vi først klargjøre hva vi legger i disse to begrepene. Begrepene lærerprofesjonalitet og samarbeid vil derfor bli behandlet hver for seg før vi presenterer datagrunnlag og metode. Deretter analyser vi våre empiriske data. Til slutt sammenfatter vi funnene og svarer på forskningsspørsmålet.

Det finnes flere teorier om lærerprofesjonalitet. Her skal vi avgrense oss til å anvende Dales $(1989,1993,2001)$ teori om lærerprofesjonalitet siden den egner seg godt som utgangspunkt for en empirisk undersøkelse av denne praksisopplæringa. Dreyfus og Dreyfus (1986) og Lave og Wenger (1991) har generelle teorier om læring av ferdigheter for yrkesutøvere, som vi mener egner seg for å se i sammenheng med Dales teori.

Dette forskningsprosjektet er nyskapende på to områder. For det første har vi i studien tatt utgangspunkt i Dales $(1989,1993,2001)$ teori om profesjonell kompetanse på det pedagogiske området. Det ble gjennomført en analyse av en praksisopplæring for yrkesfaglærerstudenter, som ifølge forskrift om rammeplan for praktisk-pedagogisk utdanning for yrkesfag for trinn 8-13 (Kunnskapsdepartementet, 2013) har som formål å styrke deres pedagogiske kompetanse og pedagogiske profesjonalitet.

Dales begreper K1, K2 og K3 ble operasjonalisert for å kunne analysere datamaterialet som vi samlet inn via gruppeintervjuer med de ti studentene som deltok i denne typen praksisopplæring. Praksisperioden strakte seg over sju måneder.

Vi kjenner ikke til noen tilsvarende analyse av en bestemt type undervisningsforløp. Barstad (2010) har riktignok også benyttet seg av Dales modell, men da i en generell drøfting av begrepet lærerprofesjonalitet, på grunnlag av intervjuer med seks grunnskolelærere.

For det andre hviler praksisopplæringa vi har analysert på gruppebasert samarbeidslæring. Vi begynte utforskinga av samarbeidsbegrepet med å spørre om hva som er mulighetsbetingelsene for samarbeid. Hva skal til for at samarbeid skal komme i stand og bli vellykket eller mislykket? For å kunne trenge dypt inn 
i samarbeidsbegrepet har vi tatt for oss filosofiske teorier om samarbeid (Hegel, 1999; Honneth, 2008, 2009; Kristiansen, 2014). Dessuten har vi anvendt sosialantropologisk transaksjonsanalyse (Barth, 1994).

I vår analyse av datamaterialet har vi funnet flere eksempler på at yrkesfaglærerstudentene har gjort seg tanker om hva som får samarbeidet til å fungere eller ikke. Studentene kommer da opp med begreper og tenkemåter som samsvarer med teoriene ovenfor. Vi finner ikke at andre har gått så dypt inn i teorier om samarbeid og så undersøkt et datamateriale for å se om begreper og tenkemåter fra teoriene finnes der.

I det følgende vil vi forklare formålet med vår forskning og sette den i sammenheng med annen forskning på yrkesfaglærerprofesjonalitet. Hensikten med denne studien er å gi forskningsbasert kunnskap om et universitets opplegg for PPU-Ys praksisopplæring. Norske utdanningsmyndigheter (Kunnskapsdepartementet, 2017a) hevder at når det gjelder PPU-Y, så finnes det ikke oppdaterte forskningsbaserte evalueringer av praksisopplæringen, men at det er indikasjoner på at praksisopplæringa og praksisrelevansen bør styrkes (Kunnskapsdepartementet, 2017a, s. 11). Ni år tidligere ble det i en offentlig utredning (NOU 2008:18) diskutert betydningen av å rekruttere nok yrkesfaglærere til å dekke morgendagens behov for lærere i yrkesfagene. I utredningen ble det hevdet at det finnes en del kunnskap om studenter som begynner på PPU-Y. Mange er godt etablerte, noe som gjør at disse studentene er mindre mobile enn andre studentgrupper. Det kan derfor være hensiktsmessig, hevdet utvalget som skrev utredningen, å legge bedre til rette for modulbasert av undervisning, uten at dette går ut over helhet og sammenheng i studiet. Det er også nødvendig å organisere utdanningen med en tett oppfølging av den enkelte student gjennom hele studiet (NOU 2008:18, s. 110).

Kunnskapsdepartementet hevdet videre i 2015 at mange yrkesfaglærere blir tilsatt uten å ha en fullført lærerutdanning i forkant. I 2014 manglet omtrent 1000 yrkesfaglærere, som jobbet i skolen, en formell lærerutdanning. Kvalifiserte lærere er viktig for elevenes resultater og gjennomføring i fag- og yrkesopplæringen. Dette blir videre poengtert av Aspøy et al. (2017), som hevder at det er en spesiell utfordring knyttet til lærere som mangler formelle kvalifikasjoner for å bli fast tilsatt i skolen (Aspøy et al., 2017, s. 10). Gode lærere med oppdatert fagkunnskap gir relevant og praktisk opplæring, som igjen bidrar til at flere fullfører og består med fag- eller svennebrev. Kvalifiserte lærere er gode rollemodeller og motiverer elevene til å fullføre fag- og yrkesopplæringa (Kunnskapsdepartementet, 2015, s. 9). Aspøy et al. (2017) rapporterer at rektorene legger på sin side noe mer vekt på behovet for å styrke lærernes pedagogiske kompetanse, i vid forstand. Rektorene mener det blant annet er behov for å utvikle lærernes analytiske evner og kompetanse i grunnleggende digitale ferdigheter (Aspøy et al., 2017, s. 8). 


\title{
Fra nybegynner til ekspert: Fenomenologiske teorier om læring av yrke
}

Fenomenologisk teori er en etablert teoritradisjon når det gjelder å forstå hva som kjennetegner yrkeskompetanse, og hvordan kompetanse utvikles. Hiim forklarer det slik:

\begin{abstract}
Fra et pragmatisk perspektiv er det et grunnprinsipp at yrkeskompetanse blir utviklet og vurdert i daglige, praktiske kontekster. Både oppgaver som vurderes underveis og oppgaver som velges ut til formell sluttvurdering må primært være en form for helhetlige eksempeloppgaver som er egnet til å stimulere og vise elevens evne til å definere, planlegge, praktisk gjennomføre, beskrive, teoretisk begrunne, vurdere og kritisere sentrale oppgaver i yrket. Det er viktig at oppgavene gir elevene muligheter for å involvere seg og til å utvise selvstendig dømmekraft. (Hiim, 2020, s. 62)
\end{abstract}

Johannesen $(2015,2019)$ har forsket på hvordan yrkesfaglærere har lavere anseelse enn allmenfaglærere i videregående skole, fordi de har mindre kulturell kapital enn disse. Noe som har sammenheng med deres utdanning og yrker, og som igjen fører til at yrkesfag blir lavere prioritert enn allmennfag. Kan det tenkes at statusen til yrkesfag vil stige når yrkesfaglærerne skaffer seg pedagogisk utdanning? Lensjø har i sin doktoravhandling studert fag- og yrkesopplæring i opplæringskontor og på byggeplass, og hun plasserer seg også innenfor denne fenomenologiske tradisjonen (Lensjø, 2016).

Dreyfus og Dreyfus (1986) og Lave og Wenger (1991) er sentrale teoretikere innen denne retningen. Brødrene Dreyfus mener at læringsprosesser kan gjennomgå fem trinn eller stadier. Trinnene kjennetegnes ved en tiltakende grad av internalisering og umiddelbarhet i kunnskap og ferdigheter.

1. Novice, nybegynner: På dette trinnet poengteres det at nybegynneren er avhengig av regler. Novisen følger reglene slavisk, og utførelsen blir tilsvarende mekanisk og hakkete.

2. Advanced beginner, viderekommen eller avansert begynner. Trinn to kjennetegnes ved at den avanserte nybegynneren fremdeles er avhengig av instruksjoner utenfra, men har tilegnet seg et større repertoar av handlingsalternativer enn nybegynneren. Fortsatt er erfaring på egen kropp blant annet gjennom å prøve og å feile i dette og de påfølgende trinn av læreprosessen viktigere enn noen form for kontekstuavhengige og eksplisitte, verbalt formulerte regler og fakta (Flyvbjerg, 1997, s. 26).

3. Competence, kompetent utøver. Den kompetente utøveren er blitt mer selvstendig. På dette nivået forholder ikke personen seg til instruksjoner for enkelthandlinger, men setter disse sammen til strategier, som hun forholder seg til. Hun er også i stand til å vurdere ulike strategier opp mot hverandre i lys av formålet med prosjektet. Nå kan hun ta avgjørelser på egen hånd, og hun har ikke lenger behov for en instruktør som følger henne tett opp. Dette stadiet tilsvarer sånn noenlunde avslutningen av opplæringsfasen på en arbeidsplass. Utøveren er 
kompetent i jobben og kan overlates til seg selv. Hennes atferd begynner å bli mer i flyt og bedre tilpasset den konkrete kontekst. Hun kan ta ansvar for planlegging og ta ansvar for konsekvensene av valget av plan (Flyvbjerg, 1997, s. 29).

4. Proficiency, kyndig utøver eller profesjonell. Den kyndige eller profesjonelle utøveren har i stor grad internalisert og automatisert en lang rekke av situasjonsforståelser. Hun innsnevrer intuitivt de interessante alternativene til noen få og velger så typisk det beste i situasjonen. Det er typisk at utøveren er dypt involvert i sine handlinger og har utviklet perspektiv på grunnlag av forutgående hendelser og erfaringer (Flyvbjerg, 1997, s. 30).

5. Expertise, ekspert. Eksperten bruker sin intuisjon og kan ikke forklare hvordan hun kommer til sine konklusjoner. Hun har ingen regler som kan konkluderes i en forklaring. Kort sagt, eksperten både oppfatter og handler intuitivt. For Dreyfusbrødrene er denne ekspertmodellen generell, og er ment å gjelde for all ekspertise.

Lave og Wenger (1991) ser på læring som plassert i sosial sammenheng, i praksisfellesskap (communities of practice). Læring er vesentlig sosial, læring er ikke å motta faktakunnskap eller informasjon. Når man studerer læring, må man derfor først se personene, virksomheten og verden som noe som konstituerer hverandre gjensidig. En person som skal lære, er først en praktikant, så en nykommer, som blir en veteran i et praksisfellesskap. Personens kunnskap, ferdigheter og ordforråd utvikler seg som del av en identitet som er under utvikling. Medlemskap/identitet er knyttet til motivasjon, og forbinder mening og handling i denne verden. Situert læring har blitt omformet til legitim ytre deltakelse i praksisfellesskap. De bruker disse eksemplene på læring for å illustrere sin teori:

1) Jordmorlære i Yucatec, 2) skredderlære i Vest-Afrika, 3) kvartermester i USmarine, 4) kjøttskjærer i amerikanske supermarkeder og 5) ikke-drikkende alkoholiker i Alcoholics Anonymous.

Yrkesfaglærerstudentens profesjonelle bevissthet og faglig skjønn utvikles gjennom erfaring og gjennom handling. Erfaringslæring er å forstå som det å lære av å reflektere over praksis (Hiim, 2010, 2013; Schön, 1983; Strømfors \& EdlandGryt, 2013). Elementer av erfarings- og handlingskunnskapen vil være tause i den forstand at de ikke kan la seg språklig verbalisere. Schön viser i studier av yrkesutøvelse hvordan kunnskap kommer til syne i handling, hvordan utøvere reflekterer fortløpende i handlingen mens den pågår, og ofte hvordan de også ofte reflekterer bevisst over handlingen i ettertid (Hiim, 2013, s. 64). Den praktiske handlingskunnskapen tilegnes ved å utøve bestemte arbeidsoppgaver og i ettertid reflektere over utøvelsen (Schön, 1983; Strømfors \& Edland-Gryt, 2013). Dette er også sentrale yrkespedagogiske prinsipper samtidig som det krever trening og øvelse for å utvikle praktiske, konkrete ferdigheter. Kunnskap kan fra et perspektiv deles inn i to hovedkategorier: eksplisitt og taus kunnskap. Den eksplisitte kunnskapen kan forholdsvis enkelt formuleres ved hjelp av ord, tall og symboler, og kan dermed relativt lett overføres til andre. Den tause kunnskapen 
er derimot vanskeligere å artikulere og kommunisere. Skillet mellom eksplisitt og taus kunnskap går i stor grad mellom det å vite og det å kunne (Johannessen \& Olsen, 2008, s. 171-172).

Taus kunnskap er et begrep fra Polanyi (1966). Det har vært vanlig å oversette hans begrep "tacit knowledge" med taus kunnskap. Det er flere som har hevdet at det er en fare for at denne oversettelsen kan føre til tro på at den tause kunnskapen alltid er utilgjengelig, uutsigelig eller uartikulerbar. Dette er ikke i tråd med Polanyis budskap, han mener tvert imot. Hans to sentrale poeng er at den tause kunnskapen ofte, men ikke alltid, kan formuleres eksplisitt i en påstandsform, og at eksplisitt kunnskap må hvile på og forutsette en taus kunnskap (Collins, 2010; Grimen, 1991, 2008; Johannessen \& Olsen, 2008; Lave \& Wenger, 1991; Lyngsnes \& Rismark, 2011; Nielsen \& Kvale, 1999; Polanyi, 2000; Rafoss \& Witsø, 2014; Stousland \& Witsø, 2015; Strømfors \& Edland-Gryt, 2013; Witsø, 1999; Åsvoll, 2009).

Polanyis utgangspunkt for begrepet taus kunnskap er at det enkelte menneske vet mer enn det kan kommunisere verbalt til andre (Polanyi, 2000; Schön, 1983; Strømfors \& Edland-Gryt, 2013). Å utvikle faglig bevissthet og skjønn er bare mulig ved å handle - å gjøre oppgaver og reflektere over det som blir gjort før det skal gjøres, mens det gjøres, og etter at det er gjort. Denne modellen for praksisopplæring som strukturerer opplæringa etter et gitt system der det gis oppgaver som det må reflekteres over, vil kunne bidra til en kompetent profesjonell bevissthet hos yrkesfaglærerstudenten. Utvikling av taus kunnskap og faglig skjønn vil kunne skje under forutsetning av at studenten får anledning til å dokumentere arbeidet sitt og reflektere over det som er gjort, alene, sammen med kolleger og en kyndig veileder.

Vi har nå lagt et grunnlag for å utforske begrepet lærerprofesjonalitet. Profesjonalitet betegner lærernes dyktighet i å utøve arbeid av god kvalitet. Profesjonell kompetanse forbinder Dale med en kombinasjon av handlingsdyktighet og innsikt innenfor en avgrenset kontekst som kompetansen gjelder for. I skolen, mener Dale, har den profesjonelle kompetansen ansvar for læring som et avgjørende kjennetegn. Dette ansvaret har to dimensjoner: på den ene siden lærerens autonomi når det gjelder organiseringen av læringsarbeidet, og på den andre siden kravet om å begrunne gyldigheten i avgjørelser og handlinger både overfor kolleger, elever, foreldre og andre samfunnsinstanser. Dale forbinder også profesjonell kompetanse med forskjellige praksiskontekster (Dale, 2001, s. 5-6). For å konkretisere lærerprofesjonalitetsbegrepet tar vi utgangspunkt i Dales (1989, 1993, 2001) begrep om didaktisk rasjonalitet og kompetanse på tre ulike områder. Han deler inn i følgende tre kompetanseområder: Kompetanse 1 (K1), kompetanse 2 (K2) og kompetanse 3 (K3) innenfor didaktisk rasjonalitet, som alle er nødvendige i den moderne skolen, og som en kompetent lærer bør beherske: K1 dreier seg om å gjennomføre undervisning, og der er relasjonen mellom lærer og elev sentral. K2 handler ikke direkte om å undervise, men om å overveie, 
planlegge og vurdere egen og andres undervisning relatert til læreplanen(e). Praksiskonteksten blir her ikke mellom lærer og elev, men mellom de ansatte på skolen som kolleger. K3 handler om kommunikasjon og konstruksjon av didaktisk teori. Dale hevder at den profesjonelle lærer er dyktig til å stille relevante og vesentlige spørsmål om de beste betingelser for elevens læring (Dale, 1989, s. 4273, 2001, s. 5-28; Aarkrog, 2018).

Vi har i løpet av arbeidet med å analysere våre data og bearbeide dem teoretisk oppdaget at Dales bruk av begrepene K1, K2 og K3 ikke er presise nok. Noen ganger betegner han dem som kompetansenivåer (for eksempel Dale 1993, s. 2021, 2001, s. 23) og andre ganger som praksiskontekster eller kompetanseområder. Dette virker forvirrende inntil man blir klar over denne tvetydigheten hos Dale. Hvis vi tolker kompetansenivå til å bety det samme som kompetanseområde, faller denne tvetydigheten bort. Dales K1, K2 og K3 betegner ulike praksisområder innenfor lærerprofesjonen: undervisning i klasserommet, refleksjon over undervisning og samhandling og erfaringsutveksling med et lærerkollegium.

Det blir da mulig å relatere Dales teori om de tre kompetanseområdene med Dreyfus og Dreyfus kompetanseskala fra nybegynner til ekspert og Lave og Wengers skala med praktikant, nykommer og veteran. K1, K2 og K3 er ikke ulike nivåer på en og samme skala, men ulike praksisområder som er kvalitativt forskjellige og ikke kvantitativt forskjellige. K1, K2 og K3 kan derfor ikke rangeres som ulike nivåer på en og samme skala. Hvis vi holder oss til Dales omtale av K1, K2 og K3 som kompetanseområder eller praksiskontekster, gir det mening å snakke om kvalitet innenfor hvert av disse kompetanseområdene på samme måte som Dreyfus og Lave og Wenger gjør det i sine teorier. Dette innebærer at vi kan si at studenten kan øke sitt kompetansenivå innenfor hvert av de tre kompetanseområdene $\mathrm{K} 1, \mathrm{~K} 2$ og K3. Dale ønsker å bestemme hva som inngår i en lærers profesjonalitet og sier at en lærer må ha kompetanse på alle områdene K1, K2 og K3. Kompetanse på området K3 forutsetter at man har kompetanse på K1 og K2. Det er K3-kompetansen som er avgjørende for om du er profesjonell som lærer. En lærer kan være flink til å undervise i klasserommet (K1) og til å reflektere over egen undervisning (K2), men hvis læreren ikke kan samhandle og utveksle erfaringer med et lærerkollegium og ha en vitenskapelig forståelse av det som skjer i skolen (K3), er læreren ikke profesjonell. Men kanskje bare en flink lærer.

Ertsås og Irgens drøfter begrepet lærerprofesjonalitet innenfor en teoretisk horisont som er nær beslektet med Dales teori. De skiller mellom teori som er innvevd i praksis, T1, teori som formulerer praksis, T2, og forskningsbasert kunnskap, T3. For at lærere skal være profesjonelle må de evne å reflektere over T1 og T2 på T3-nivå (Ertsås \& Irgens, 2012, s. 195-213).

Får yrkesfaglærerstudentene i denne undersøkelsen trening og oppøving av didaktisk kompetanse på disse tre områdene ved å gjennomføre praksisopplæring med egne elever på egen skole i samarbeid med medstudenter? Vi har 
analysert intervjuene med studentene og identifisert hva de sier om hva de har erfart, og plassert dette i forhold til K1, K2 og K3.

\section{Hva er "mulighetsbetingelsene" for samarbeid?}

Honneth $(2008,2009)$ har foretatt en filosofisk analyse av betingelsene for at et samfunn kan oppstå og bestå. Han knytter an til tradisjonen fra Hegel og Marx, som kort sagt går ut på at menneskene er samfunnsmessige vesener i utgangspunktet, noe som betyr at individene konstitueres som individer i samspill med andre individer. Denne konstitueringa skjer som en kamp om anerkjennelse av at hver enkelt har rettigheter og krav på respekt. Denne anerkjennelsen må være gjensidig. Hegel bruker som eksempel på ensidig anerkjennelse forholdet mellom herre og trell. Herren forlanger å bli anerkjent av trellen, mens han ikke anerkjenner trellen som en som har rettigheter og krav på respekt. Dette forholdet er utilfredsstillende for herren fordi trellens anerkjennelse av ham ikke er mye verdt, siden trellen ikke er like mye verdt som ham selv. Det er bare gjensidig anerkjennelse mellom likeverdige individer som gir en tilfredsstillende anerkjennelse (Hegel, 1999, s. 118).

Likeverd, anerkjennelse og gjensidig respekt mellom parter som må samarbeide, gir grunnlag for at partene vil kunne ha tillit til hverandre. Følgende definisjon av tillit er representativ for hvordan begrepet blir definert innenfor samfunnsvitenskap, pedagogikk og filosofi i våre dager: "Det å frivillig gjøre seg sårbar og utsette seg for en risiko overfor andre, samtidig som en forventer at den andre ikke vil misbruke tilliten" (Rafoss, 2009, s. 19).

Kristiansen skriver om tillit og kommunikasjon i ulike samarbeidsprosesser, og hun behandler to ulike prosesser: dialog, der partene har felles interesser, og forhandlinger, der partene har motstridende interesser. I begge tilfeller er det nødvendig at partene har tillit til hverandre for at samarbeidet skal bære frukter. I en dialog er "Det avgjørende ... å føle seg velkommen, å bli lukket inn og slik bli en del av et gjensidig forpliktende fellesskap der man vil hverandre vel" (Kristiansen, 2014, s. 140). Mens i forhandlinger er en i utgangspunktet mistroiske til hverandre fordi en har motstridende interesser. Det må derfor skapes tillit mellom partene for at de skal bli enige om en avtale.

Yrkesfaglærerstudenter som skal gjennomføre en praksisperiode med egne elever på egen skole, der de må arbeide i ei gruppe, og der de er gjensidig avhengig av hverandre, har samme interesse av å fullføre praksisopplæringa. Det er ikke slik at én kan vinne noe på bekostning av de andre. Dette er en situasjon som legger til rette for dialog mellom gruppemedlemmene. De eneste risikoene de tar, er at de kan komme i gruppe med en student som vil være gratispassasjer eller ikke er dyktig nok til å gjennomføre de pålagte oppgavene. Studentene tar med andre ord en viss risiko når de går inn i dette opplegget. Men samtidig viser 
de sine medstudenter tillit når de utsetter seg for denne risikoen fra sine medstudenter.

For å forstå fenomenet samarbeid fra en annen synsvinkel kan vi trekke inn sosialantropologen Barths (1994) transaksjonelle modell for samfunnsmessig samhandling. Barth hevder at nesten all sosial samhandling kan betraktes som transaksjoner mellom individer eller grupper. Transaksjoner vil si bytte av verdier:

\begin{abstract}
Men vi lever stadig med transaksjoner, og et klart begrep om transaksjon fører til innsikt i en svært grunnleggende prosess; den prosessen som oppstår når partene gjennom sin samhandling systematisk prøver å forsikre seg om at verdien av det som oppnås er større eller lik verdien av det som ytes.
\end{abstract}

Når de fremstilles slik, kan en se at transaksjoner har en struktur som tillater oss, ved hjelp av en strategisk modell, å analysere dem som strategiske spill. De består av sekvenser av gjensidige ytelser som representerer trinnvist etterfølgende steg $i$ spillet. Det føres regnskap over gevinst og tap av verdier, og hver påfølgende handling, eller hvert steg, påvirker dette regnskapet, endrer den strategiske situasjonen og kanaliserer senere valg. (Barth, 1994, s. 37)

Den verdien som studentene gir og mottar fra de andre studentene som de er i gruppe sammen med, er arbeidstid. Hver student har plikt til å yte det samme overfor de andre studentene, og hver student har rett til å motta det samme fra de andre studentene. Dermed vil alle oppnå "at verdien av det som oppnås er større eller lik verdien av det som ytes". Og det er nettopp dette som er tanken fra universitetets side, og som gjør det trygt for studentene å bli med i ei slik gruppe.

På grunnlag av en litteraturgjennomgang av 14 metastudier av gruppelæringsaktiviteter har De Hei et al. (2018) laget et rammeverk der de skiller mellom åtte komponenter ved utformingen av gruppelæringsaktiviteter: (1) interaksjon, (2) læringsmål og resultater, (3) vurdering, (4) oppgaveegenskaper, (5) strukturering, (6) veiledning, (7) gruppekonstellasjon og (8) fasiliteter. I tillegg blir sammenhengen mellom de enkelte komponentene understreket som avgjørende for utformingen av en gruppelæringsaktivitet. Studentenes svar viste at de oppfattet at de tilegnet seg to typer ferdigheter: akademiske ferdigheter og nøkkel- eller overførbare ferdigheter som kan betraktes som læringsutbytte relatert til framtidas yrke når det gjelder utvikling av sosiale ferdigheter, ferdigheter for implementering av gruppelæringsaktiviteter i klasserommet i framtida, og samarbeidsevner for utvikling i lærerprofesjonalitet.

De fant ut at lærerutdannere opplever problemer særlig med utformingen av hvordan studentene skal samarbeide i løpet av en gruppelæringsaktivitet, med andre ord måten samarbeidet er strukturert på. Eksempler på strukturering er bruk av roller, fordeling av ressurser blant studenter for å gjøre dem gjensidig avhengige, og fagfellevurdering som en del av vurderingen. Gruppelæringsaktiviteter der struktureringen av samarbeidet ikke blir vektlagt, kan føre til gratispassasjerer blant studentene. 


\section{Empirigrunnlag og metode}

Datagrunnlaget vårt er intervjuer gruppevis med i alt ti yrkesfaglærerstudenter i praksis ved praktisk-pedagogisk utdanning for yrkesfaglærere (PPU-Y). Alle ti er tilsatt i videregående skoler. I forskrift om rammeplan for praktisk-pedagogisk utdanning for yrkesfag for trinn 8-13 framgår det at studenter som er tilsatt i skolen, kan ha femti prosent av praksis på egen skole med egne elever (Kunnskapsdepartementet, 2013). Ved ett universitet i Norge gis det et slikt tilbud om praksis, og det er et kull av slike studenter vi har forsket på. Tilbudet gjelder studenter som har anledning til å gjøre forpliktende avtale om å delta i ei gruppe for å samarbeide om egen og hverandres utvikling av lærerkompetanse.

Praksisopplæringa startet tidlig på høsten, og studentene ble delt i tre grupper. Det var fire menn og seks kvinner med ulik utdannings- og fagbakgrunn, og de kom fra seks videregående skoler og fem forskjellige yrkesfaglige utdanningsprogrammer. Studentene hadde vært tilsatt i skolen fra ett til fem år, og hadde i gjennomsnitt cirka tjue års yrkeserfaring i fagområdene sine. Mennene har yrkesfaglig bakgrunn fra håndverk og industri med minimum et fagbrev og to års fagskole. Kvinnene har enten helsefaglig kompetanse eller bakgrunn fra service og samferdsel. De har alle videreutdanning innenfor sine fagfelt.

Det var bestemt i detalj hvordan samarbeidet skulle foregå. Studentene lagde i september en datoplan for når den enkelte skulle undervise og bli observert. Studenten som underviste, fylte ut planleggingsskjema og sendte det på forhånd til medstudenten, som skulle observere og gi tilbakemelding. Studenten som var observatør, ga tilbakemelding og fylte ut struktureringsskjema et gitt antall ganger. For nærmere beskrivelse av praksis på egen arbeidsplass, se Universitetet i Agder (2020).

I tillegg til intervjumaterialet, som gir grunnlag for å vurdere studentenes egen oppfatning av samarbeidet og praktiseringen av lærerprofesjonen, har vi også hatt tilgang til alt det skriftlige materialet som studentene måtte produsere i løpet av dette studieforløpet. Praksisdokumentene består av ulike skjema for observasjon, veiledning, undervisningsplanlegging og et skjema kalt "Min lærerprofil". Utviklingen av dette skjemaet er inspirert av boka "Mein" Kompetenzprofil av Karner (2012) og er ment å være et redskap for refleksjon over egen profesjonsutvikling. "Min lærerprofil" er et dokument der studenten skal krysse av på egen oppfatning av kompetanse når det gjelder didaktisk kompetanse, faglig, sosial og yrkesetisk kompetanse. Likeså skal studenten reflektere over egen evne til å lede opplæring og evne til å ta imot veiledning og å endre seg som resultat av veiledningen. I skjemaet er det mange konkretiseringer av hva det innebærer å oppnå kompetanse innenfor disse seks ulike områdene. Dette skjemaet fyller studenten ut alene ved praksisperiodens start. Mot slutten av perioden, fyller studenten ut det samme skjemaet en gang til, men nå i en ny kolonne. Etter at studenten har fylt ut kolonne nummer to samles gruppa (på fire eller fem deltakere) til møte og 
går gjennom egen utvikling med de andres kommentarer. Møtet ledes av veileder. Dette er den samme gruppa som har fulgt hverandre opp gjennom observasjon og veiledning i løpet av praksisperioden. Det blir presisert av universitetet at arbeidet med "Min lærerprofil" er et personlig utviklingsarbeid som har til hensikt bidra til økt læringsutbytte og større innsikt i egen utøvelse av lærerprofesjonen. Praksisdokumentasjonen består av i alt 140 dokumenter.

Videre observerte en av forfatterne hver student i minimum to undervisningsøkter på minimum 90 minutter og hadde deretter samtaler med student og observatør. Alt dette ga en fyldig bakgrunnskunnskap når det gjaldt å tolke intervjuene. Det er små muligheter for at vi skal ha tolket intervjuene feil.

Studentene ble spurt muntlig og skriftlig om de kunne tenke seg å være deltaker i en studie om yrkesfaglærerstudenters samarbeid om utvikling av egen og hverandres lærerprofesjonalitet. Det ble poengtert at dette var forskning og ikke en evaluering av PPU-Y. De fikk beskjed om at all deltakelse var basert på frivillighet, og ble fortalt at det ikke ville få noen konsekvenser for dem dersom de ikke ønsket å delta, eller valgte å trekke seg underveis. Dette ble klargjort fordi den ene av oss to forfattere også er studentenes veileder i praksisopplæringa.

Intervjuene som ble gjennomført, var semistrukturerte fokusgruppeintervjuer. Vi stilte gruppene fjorten åpne spørsmål og fungerte for øvrig som ordstyrer i samtalene mellom gruppedeltakerne (Johannessen et al., 2004, s. 145). Det ble gjort lydopptak, og så ble intervjuene transkribert ordrett.

Vårt forskningsspørsmål er: Hvordan kan gruppesamarbeid mellom yrkesfaglærerstudenter bidra til å utvikle deres lærerprofesjonalitet? Det spørres her etter sammenhengen mellom samarbeid og lærerprofesjonalitet, og vi får dermed to temaer som vi må søke etter i intervjuene.

Meningsinnholdet i tekstmaterialet ble analysert ved å kategorisere utsagnene som kom fram i intervjuene. Denne tilnærmingen utforsker og beskriver mennesker og deres erfaringer med og forståelse av et fenomen, her strukturert og ustrukturert samarbeid mellom yrkesfaglærerstudenter i praksis. (Creswell, 2009, s. 57; Johannessen et al., 2004, s. 76).

Den første fasen i analysen av intervjumaterialet gikk ut på å danne seg et helhetsinntrykk og gi en sammenfatning av meningsinnholdet (Johannesen et al., 2018, s. 125-127 og 133-135; Johannessen et al., 2004, s. 173).

Det viste seg at studentenes utsagn falt inn under seks kategorier når de snakket om samarbeid, og under åtte kategorier når de snakket om lærerprofesjonalitet. I analyseavsnittet blir disse kategoriene listet opp, og det blir dokumentert hvordan utsagn $i$ intervjuene faller inn under de respektive kategoriene. 


\section{Analyse av hva yrkesfaglærerstudentene fortalte om lærerprofesjonalitet}

Dale hevder at didaktisk kompetanse er kompetanse sammensatt av tre kompetanseområder; K1, K2 og K3. Den første, K1, gjelder lærerens handlinger og overveielser i den umiddelbare organiseringen av undervisning og læringsarbeid. Handlingene og overveielsene i øyeblikket er preget av handlingstvang, og kommer til uttrykk i realiseringen av undervisning forbundet med elevenes læringsarbeid (Dale, 1993, s. 67, 2001, s. 6).

I denne studien, der datamaterialet er intervjuer med yrkesfaglærerstudenter i praksis med egne elever på egen skole, bar ikke samtalene preg av å være på $\mathrm{K} 1$, fordi samtalene var om undervisning og diskusjoner om handlingene og samtalene mellom lærer og elever etter at undervisningen var over.

De tre studentgruppene hadde flere eksempler og samtaler seg imellom om hvordan de lærte ved å bevege seg på kompetanseområde K2. Dette kompetanseområdet omhandler lærerens læringsansvar innenfor et kollegialt fellesskap. Alle studentene i undersøkelsen er som nevnt tilsatt i skolen og har det nasjonale læreplanverket som et viktig mandatgrunnlag for sin tilrettelegging og vurdering av opplæringa (Kunnskapsdepartementet, 1998). Studentene planla, gjennomførte, vurderte og dokumenterte sin undervisning i klasserom og verksted etter en didaktisk modell kalt den triadiske modellen. I modellen er det utviklet egne planleggings- og observasjonsskjemaer som ivaretar studentenes muligheter til å ta hensyn til alle faktorer som påvirker undervisning og tilpassing. Planlegging og vurdering foregår før og etter undervisningen. Mens læreren er under handlingstvang i K1, vil det være svekket handlingstvang i K2 fordi det vil være mer tid til overveielser og mindre press på avgjørelser enn under gjennomføring av undervisning (Dale, 2001, s. 11).

I vårt materiale fant vi utsagn som tilhører fire kategorier som kan sies å være på området K2, læringsansvar innenfor et kollegialt fellesskap. Kategoriene var: 1. Undervisningsplanlegging, 2. Observasjon, 3. Veiledning og tilbakemelding og 4. Organisering.

Alle studentene i undersøkelsen fortalte om sine erfaringer med å forberede sin undervisning. De var pålagt av universitetet å dokumentere at de mestret å planlegge sine økter ved hjelp av bestemte skjemaer. Følgende tre uttalelser kan stå som eksempler på studentenes erfaringer med å planlegge egen undervisning:

Jeg syns at det planleggingsskjemaet er mer og mer interessant. For hver gang jeg lager det så blir jeg flinkere til å bli mer detaljert. Jeg kan faktisk se hvor lang tid jeg trenger i en undervisningsøkt. Du greier liksom mer å planlegge på en bedre måte. Og jeg tenker at etter hvert så har du kanskje det litt inn i ryggmargen da, den måten å planlegge på. Altså det er jo et veldig bra verktøy, selv om at det er ... 
Jeg syns det var en pest og en plage i begynnelsen, og jeg tenkte hva er vitsen med det her, er det ikke helt overdrevent, tenkte jeg. Og det er først nå mot slutten jeg begynner egentlig å skjønne viktigheten av det.

Det har vært lærerikt å forberede egne økter. For da tenker jeg at da er jeg nødt til å gi litt ekstra jern ikke sant. Og da lærer jeg triks både om å effektivisere egen planlegging, men også hva som er viktig å legge vekt på.

Denne siste uttalelsen stemmer overens med en annen studie (Zwart et al., 2009, sitert i Postholm, 2012, s. 32), som viser at dersom lærere observerer hverandre og gir hverandre tilbakemeldinger på praksisen som er observert, fører det til positiv endring i undervisningspraksis. Når lærerne vet at de skal observeres, føler de et visst press for å eksperimentere og modellere nye undervisningsstrategier for den som observerer.

Under kategoriene observasjon og veiledning/tilbakemelding hadde alle informantene uttalelser som vektlegger betydningen av de tilbakemeldingene de både fikk og ga på grunnlag av observasjon av undervisning. Følgende utsagn kan stå som typisk og representativt for alle:

Jeg syns vi har veiledet hverandre ok og med respekt for hverandre. Jeg har fått mange gode tilbakemeldinger, og vi har prøvd å justere oss litt etter det. $O g$ så syns jeg også vi samarbeider veldig bra, vi har liksom respekt for hverandre og prøvd å fă det så greit vi kan til for at det skal bli greit for alle. Vi er jo i full jobb de fleste.

Kategorien organisering handler om hvordan studentene har ordnet samarbeidet seg imellom etter ansvarsfordeling gitt av universitetet. Det er flere eksempler på at respondentene forteller både om egen undervisning og om observasjon av andres undervisning. En student forteller om opplegget på denne måten:

\begin{abstract}
Når vi kommer sammen så har vi fått et planleggingsskjema av den vi skal observere. Så skriver vi ganske detaljert observasjon av den undervisningen, eller det opplegget som kollegaen da går igjennom. Prøver å notere litt ting som kanskje skjer bak scenen også. Får med seg det som skjer i klasserommet. Hvilken effekt undervisningen har. Konkret hva som blir undervist. Noterer og klokkeslettet for å se om han klarer å holde seg til den planen han har lagt for timen, og så i etterkant går vi gjennom og ser på hva som var positivt, hva som kan forbedres, og prøver å ha en dialog på hva som timen har dreid seg om og endringer, og hva som er lurt å tenke på videre fremover.
\end{abstract}

Videre i materialet fant vi utsagn som falt inn under fire kategorier under kompetanseområde 3 (K3), Konstruksjon og kommunikasjon i teori om kvalitet i skolen. Disse var: 1. Nyutvikling, 2. A identifisere seg med lærerrollen, 3. Å lære av andre skoler eller andre avdelinger på samme skole, og 4 . Å lære av hverandres likheter og forskjeller.

Alle respondentene hadde mange års erfaring fra arbeidslivet i sine tidligere yrker. Det var interessant å merke seg hvordan de samtalte om hvordan de 
utviklet seg i sin andre profesjon, læreryrket og lærerrollen, gjennom å samarbeide med hverandre. En av studentene sa dette:

Jeg tror det er lett å gå inn i en sånn copy-paste fra år til år hvis du ikke bryner deg pà andre kolleger eller medstudenter. ... man kjører det samme løpet om igjen og om igjen hvis man ikke har tett samarbeid med andre. Sånn at man utvikler seg $i$ lærerrollen gjennom samarbeid.

Et annet eksempel som kan illustrere yrkesfaglærerstudentens utvikling mot lærerprofesjonalitet på Dales kompetanseområde K3:
Ja, altså når vi jobber i verkstedet så jobber vi parallelt. To lærere i to forskjellige haller med ei dør mellom oss. Og det er klart, sånn som vi har jobbet her vil jeg jo på en måte ... ser jeg noe som jeg lurer på som skjer i den andre klassen så vil jeg stille spørsmålet ved det for å heve kvaliteten i hele avdelinga. Jeg tenker at samar- beid har gjort at jeg er tøffere til å ta opp ting med andre lærere.

Denne yrkesfaglærerstudenten gir uttrykk for at han har blitt modigere gjennom å øve seg på å stille spørsmål der det forventes en atmosfære som gjør det mulig å gjennomføre pedagogiske samtaler der en må svare for seg. Denne uttalelsen kan illustrere at en profesjonell lærer er aldri ferdig utlært og vil aldri slutte å spørre hvordan han eller hun kan gi eleven de beste betingelser for læring (Dale, 1993, s. 107, 2001, s. 9). Dette er en student som beveger seg på kompetanseområde $\mathrm{K} 3$.

Følgende utsagn fra en student kan stå som eksempel på hvordan deltakerne gjorde selvanalyser og arbeidet med å utvikle sine evner til å føre argumentative dialoger ved å bevege seg fra K1 til K2, K3 og tilbake igjen.

Planleggingsskjema er bra for struktur og planlegging, men virkeligheten går jo ikke alltid helt etter boka, ... for jeg syns jo også det er spennende å komme inn $\mathrm{i}$ en time hvor det skjer et eller annet, og «oi hvordan takler læreren det?» Så det er det eneste jeg savner her; at det blir litt for perfekt. Men, det hadde jo vært gøy noen ganger hvis det hadde skjedd noe som hadde gjort litt sånn at man kommer i et etisk dilemma. «Hva gjør man her og nå?» For det lærer man virkelig av. Og det har jeg ikke støtt på til nå.

Dette ønsket om å få være med i en time der ikke alt "går etter boka", kan på en måte kategoriseres under K1, lærerens "handlingstvang". Utsagnet kan på en annen måte tolkes som eksempel på lærerens handlingsdyktighet, som kommer til uttrykk i lærerens innsikt i å planlegge og vurdere gjennomføringen av undervisningen. Dette er Dales område K2, Læringsansvar innenfor et kollegialt fellesskap. En lærer som er seg bevisst sin lærerrolle, vil lettere kunne tilpasse sin plan til elevenes læring i den aktuelle situasjonen (Jensen et al., 2019).

Utsagnet kan også tolkes som eksempel på en refleksjon fra en lærer som har utviklet sin kompetanse på område K3. Studentens fortelling om at det en virkelig kan lære noe av, det er å komme opp i dilemmaer der en slett ikke er sikker på at det som blir gjort i en situasjon, vil være riktige handlinger av læreren. I samtalen etter en slik hendelse vil det være mulig for den som underviser, og den 
som observerer, å utforske seg selv og hverandre ved å beskrive, fortolke, analysere og forklare hendelser og fenomener innenfor lærerrollen (Dale, 2001; Jensen et al., 2019; Aarkrog, 2018). Kompetanse på K3 kan forstås som den gode yrkesfaglæreren som samarbeider godt med kolleger og deler kunnskap, erfaringer og undervisningsopplegg innad i fagfellesskapet (Aspøy et al., 2017, s. 7).

En av studentene sa i undersøkelsen at han ville ta godt vare på planleggingsog observasjonsdokumentene han hadde samlet i løpet av praksisopplæringa, med tanke på at de kunne brukes som inspirasjon i videre studier i yrkeskarrieren. Likeså at dokumentene ville kunne anvendes når nye yrkesfaglærerstudenter skulle få praksisopplæring med ham som praksislærer. En annen student fortalte at det hadde vært enkelt å ha praksis på egen arbeidsplass fordi en «er jo på jobb». Så selv om det hadde vært krevende å være i praksis i tillegg til å være på jobben, var hun glad for kompetansehevingen utdanningen ga. Utdanningsmyndighetene skriver at i satsingen på å gi et bedre videreutdanningstilbud til lærerne er kanskje yrkesfaglærere den lærergruppa i videregående opplæring som har færrest muligheter til å få dekket sine kompetansebehov (Kunnskapsdepartementet, 2017b, s. 81). Vi mener at det som kommer fram i begge disse to studentutsagnene, nemlig å legge til rette for kompetanseheving gruppevis lokalt, er en metode som støtter opp under utdanningsmyndighetenes linje med satsing på lokal skoleutvikling.

Vi har analysert studentenes oppfatninger om egen lærerprofesjonalitet ved å anvende Dales kategorier K1, K2 og K3. Innholdet i kategoriene dukket direkte og indirekte opp i intervjuene med studentene. Dette praksisopplegget tvinger tydeligvis studentene til å samtale og reflektere over didaktiske spørsmål innenfor alle de tre kompetanseområdene. Kravet om at studentene skulle fylle ut et planleggingsskjema for hver økt, ga dem muligheter til å tenke gjennom didaktiske spørsmål på område K2. Det samme gjaldt kravet om at den studenten som var observatør, måtte gjøre feltnotater og fylle ut et struktureringsskjema som sammenfattet observasjonen. Videre måtte observatøren, etter undervisningsøkta, ha en evalueringssamtale med den som underviste, med utgangspunkt i det utfylte skjemaet.

\section{Analyse av det yrkesfaglærerstudentene fortalte om samarbeid}

Nå skal vi redegjøre for hva vi fant av uttalelser som falt inn under temaet samarbeid. Da vi studerte intervjuene, kategoriserte vi en del av utsagnene som studentene brukte når de snakket om samarbeid, under kategoriene trygghet, ærlighet, tillit, respekt, empati og omsorg. Dette er begreper som inngår i de teoriene om samarbeid som vi har redegjort for tidligere i artikkelen. De seks kategoriene ble ordnet i tre par: trygghet og ærlighet, tillit og respekt og empati og omsorg.

Hvordan har studentene opplevd samarbeidet? Og hvilke tanker har de gjort seg om det å samarbeide? Hvordan passer deres erfaringer med de teoretiske 
betraktningene om samarbeid som vi har redegjort for ovenfor? Noen av de spørsmålene vi stilte studentene i det semistrukturerte intervjuet, gikk direkte på samarbeid: Hvordan samarbeider dere? Hva er samarbeid? Hvilke former for samarbeid har dere? Hvilken betydning har samarbeid for utvikling av lærerrollen?

Intervjuspørsmålene var åpne spørsmål om samarbeid generelt, så når studentene svarte med utsagn som falt inn under de seks kategoriene, kom det spontant fra deres side. Dette er ikke en kvantitativ undersøkelse, men vi angir likevel i det følgende noen steder hoor mange som brukte begreper som faller inn under de enkelte kategoriene. Det kan si noe om hvor lett det falt i munnen å benytte seg av begreper som hører inn under de enkelte kategoriene, når de skulle fortelle om sin erfaring med det samarbeidet de har gjennomført. Vi gir nå eksempler på typiske utsagn studentene kom med, og som hører inn under de enkelte kategoriene.

\section{Trygghet og ærlighet}

Trygghet var det emnet som ble hyppigst brakt på banen av studentene. Det var ikke noe intervjuspørsmål som eksplisitt tok dette opp. Det var seks studenter som snakket om trygghet, to fra hver av de tre gruppene, og det ble nevnt åtte ganger.

To av uttalelsene om trygghet går på at trygghet er en forutsetning for å kunne samarbeide bra: En student sa at for at en skal kunne samarbeide godt, må de som skal samarbeide med hverandre, være trygge på hverandre: "... det sitter jo langt inne å samarbeide med noen du ikke ... er trygg på." En annen sa klart: "... det krever at det er god kjemi. Hvis ikke du har god kjemi så kan jo samarbeid være forferdelig." I metaforen god kjemi tolker vi at det blant annet ligger det å føle seg trygge på hverandre.

Tre studenter i to av gruppene kom inn på kategorien ærlighet. En uttalte: "Visst gjør det det. I det hele tatt, at vi lærer nok mye med å samarbeide med egen kollega når en ser at dette her funker. Sånn som vi holder på med her. Så er det viktig å ta det med seg. At en er åpen og ærlig mot hverandre."

Det å være ærlig innebærer å ta en risiko. Hvis en kritiserer en annen person, så kan denne ta det ille opp, bli fornærmet, og trekke seg tilbake fra samarbeidet. Men hvis alle i samarbeidet er overbevist om at alle vil hverandre vel, så vil en tenke at det ikke er meningen å fornærme eller vise misaktelse, men å hjelpe eller klargjøre et spørsmål for å samarbeide bedre.

\section{Respekt og tillit}

En betingelse for å kunne være trygg $\mathrm{i}$ forholdet til en annen person er at du vet at vedkommende respekterer deg. Hvis alle i ei gruppe respekterer hverandre, kan alle være trygge på hverandre fordi de har aktelse for hverandre.

Det var tre studenter fordelt på to av gruppene som snakket om respekt: "Og så syns jeg vi har veiledet hverandre ok og med respekt for hverandre." En annen 
sa: "Samarbeid handler jo mye om å respektere at vi er forskjellige. Vi er jo i forskjellige livssituasjoner, og vi er forskjellige mennesker, men allikevel så må vi greie å samarbeide med hverandre og ha respekt for våre forskjelligheter." En tredje student uttalte: "Jeg opplever dem som flinke. Jeg har også tillit til begge som sitter her, og har respekt for dem. Og da er det jo lettere å være åpen." Det sitatet knytter interessant nok tillit og respekt sammen.

"Så det har vært veldig lærerikt å ha med noen inn som ser ... altså både få litt sånn selvtillit på at noe faktisk fungerer, og hva en må jobbe med og justere på." I dette sitatet snakkes det om selvtillit. Det er ikke umiddelbart et relasjonelt begrep. Men man kan spørre om selvtillit i neste omgang gir grunnlag for å vise tillit til andre.

\section{Empati og omsorg}

Vi tenker her på empati som en persons evne til å forstå en annen persons tanker og følelser og opptre overfor personen med respekt for disse tankene og følelsene. Dette er en interessant kategori å se etter, siden empati er en forutsetning for at personer kan samarbeide på en fruktbar måte. En person viser omsorg når han bryr seg om en annen person og hjelper denne hvis det trengs. Empati og omsorg er to begreper som henger sammen: $\AA$ vise omsorg er en aktivitet, mens empati er en forutsetning for å kunne vise omsorg siden man først må forstå en annen persons tanker og følelser for å forstå at det er behov for å hjelpe på en eller annen måte.

Det er flere uttalelser som gir uttrykk for at yrkesfagstudentene har empati og omsorg for hverandre. En sier: "Jeg tror nok ... hvert fall når man er vant til å jobbe med pasienter, og vant til å jobbe med helse, så er man også vant til å tenke empati da. Vi er vant til å tenke 'hva er pasientens behov?' Og det er jo veldig overførbart til det å ha elever, tenker jeg." To andre ga uttrykk for omsorg ved å si: "Det er så viktig at man prater hverandre opp som lærer" og "Ja, jeg tror følelsen er at vi er innstilt på å gjøre hverandre gode. Ja, gjøre hverandre gode rett og slett." Flere studenter uttrykte seg på liknende måte, men vi tar bare med nok et uttrykk for omsorg: "Ja det er jo å ville hverandre vel."

En uttalelse fra en av studentene i undersøkelsen viser klart at samarbeidet oppfattes som transaksjoner der en gir og mottar en verdi, nemlig studentenes egen tid: "Det samarbeidet som man prøver å legge vekt på her, er jo det å gi til hverandre av sin egen tid. At en tar seg tid til å komme inn til hverandre og gi hverandre en tilbakemelding."

\section{Diskusjon}

Begrepet gratispassasjer definerer vi som en som er medlem av ei gruppe uten å yte noe: Hen deltar ikke i gruppas diskusjoner og produserer ikke noe av det som gruppa produserer, som er grunnlag for vurderinga av gruppearbeidet. Hen 
mottar belønning i form av vurdering uten at det har kostet noe. Hen nyter uten å ha ytt noe. Dersom organiseringa av et gruppearbeid gjør det mulig for en eller flere av studentene å være gratispassasjer, har dette flere uheldige konsekvenser for gruppearbeidet:

Gratispassasjerer overlater sin del av arbeidet til de andre gruppedeltakerne. Disse får mer å gjøre enn det som var bestemt, eller det samlede produktet blir dårligere hvis de som arbeider, ikke makter å gjøre det som gratispassasjeren skulle ha gjort. De arbeidsomme gruppedeltakerne opplever dette som urettferdig, noe som virker demoraliserende og demotiverende. Muligheten for gratispassasjerer gjør at mange studenter vil vegre seg for å delta i gruppelæringsaktiviteter i det hele tatt.

Vi oppdaget ingen tilfeller av gratispassasjerer i de gruppene vi studerte. Er det noe ved organiseringa av gruppearbeidet som forhindrer gratispassasjerer? I praksisopplæringa skal studentene levere datoplan til veileder for når de skal være til stede i hverandres undervisning, de skal sende planleggingsskjema for undervisningstimer, og når studentene er observatører i de andre studentenes timer, skal de fylle ut et struktureringsskjema. All denne dokumentasjonen skal samles i hver enkelt students praksisperm. Dessuten er veileder til stede i undervisningstimer for hver student når en av de andre studentene observerer, og med påfølgende samtale med underviser og observatør etter timen.

Denne organiseringa gjør det umulig å være gratispassasjer. Hvis en student ikke gjør oppgavene sine, vil opplegget for hele gruppa gå i stå, og lærer må straks intervenere. Studenten blir passet på og stimulert av de andre gruppedeltakerne. Lærer har også jevnlig kontakt og god dialog med hver enkelt student. Studentene har også mye å miste ved gå ut av opplegget slik at det er sterke insentiver for å gjennomføre dette gruppelæringsarbeidet. Hvordan er det mulig å vurdere hver enkelt deltakers innsats i en gruppelæringsaktivitet riktig? Hvis det gis en felles karakter for gruppearbeidet, er det mulig at noen deltakere får bedre karakter enn innsatsen deres tilsier, og at noen deltakere får dårligere karakter enn innsatsen deres tilsier. En slik mulighet vil kunne gjøre studenter skeptiske til å delta i gruppelæringsaktivitet. Når det gjelder vurdering, er sluttvurderingen bestått eller ikke bestått, slik at ingen student som fullfører, får en karakter som ikke er fortjent. Dermed blir det ikke forskjellsbehandling mellom studentene.

De Hei et al. (2018) foretok en empirisk studie av bruken av samarbeidslæring i lærerutdanningen ved nederlandske universiteter. 290 lærerstudenter fra 6 universiteter som deltok i gruppelæringsaktiviteter, deltok i denne undersøkelsen. Forskningsspørsmålene deres gikk på om det var en sammenheng mellom utformingen av gruppelæringsaktivitetene og det reint faglige læringsutbyttet og læringsutbytte sett i relasjon til framtidas profesjon. De spurte også om det var en sammenheng mellom studentenes vurdering av gruppelæringsaktivitetens struktur og engasjement og muntlige samhandling i gruppelæringsaktivitetene 
og det reint faglige læringsutbyttet og læringsutbytte sett i relasjon til framtidas profesjon. Deres funn peker på at de valg pedagoger tar i utformingen av gruppelæringsaktiviteter, bør være rettet mot å utløse engasjement og samhandling, fordi disse faktorene bidrar i betydelig grad til læringsutbyttet.

\section{Avsluttende kommentar}

Forskningsspørsmålet vi stilte da vi startet arbeidet med denne undersøkelsen, var: Hvordan kan gruppesamarbeid mellom yrkesfaglærerstudenter bidra til å utvikle deres lærerprofesjonalitet? For å finne svar, intervjuet vi yrkesfaglærerstudenter som samarbeider med medstudenter i sin praksisopplæring etter et fast og strukturert system gitt av universitetet. Vi studerte også 140 ulike planleggings-, observasjons- og kompetanseutviklingsskjema som studentene leverte inn.

$\mathrm{Vi}$ analyserte det studentene fortalte, og kategoriserte utsagnene inn under Dales begrep om didaktisk rasjonalitet og kompetanse på tre områder (K1, K2 og K3) i ulike praksiskontekster.

- Da fant vi det sannsynlig at studentene utviklet sin lærerprofesjonalitet gjennom å bevege seg på område $\mathrm{K} 1$, som er å gjennomføre egen undervisning.

- Studentene utviklet sin lærerprofesjonalitet på område K2, ved å planlegge og vurdere egen og andres undervisning og didaktiske virksomhet. De deltok som observatører i økter der det ble undervist i andre yrkesfag enn deres egne, og de besøkte andre avdelinger og skoler.

- Og de utviklet sin profesjonalitet ved å kommunisere omkring didaktisk virksomhet og selv utvikle didaktisk teori, noe som tilsvarer Dales område K3.

- Innholdet i praksiskontekstene på disse tre kompetanseområdene dukket direkte og indirekte opp i intervjuene med studentene. Praksisopplæringa gjorde det tydeligvis mulig for studentene å samtale om og reflektere over didaktiske spørsmål innenfor alle de tre kompetanseområdene.

- Kravet om at studentene skal fylle ut et planleggingsskjema for hver økt i klasserom eller verksted, utfordret dem til å tenke gjennom ulike didaktiske spørsmål. Det samme gjaldt kravet om at den studenten som var observatør, måtte gjøre feltnotater og fylle ut et struktureringsskjema som sammenfattet observasjonen. Videre måtte observatøren, etter undervisningsøkta, ha en vurderingssamtale med den som underviste, med utgangspunkt i det utfylte skjemaet. I tillegg måtte studentgruppa forplikte seg på å gjennomføre et møte mot slutten av praksisperioden der den enkelte student først redegjorde for sin egen profesjonelle utvikling for deretter å få tilbakemelding fra de andre i gruppa og veileder.

- De sentrale kategoriene i teoriene til Hegel, Honneth, Kristiansen (anerkjennelse, respekt, tillit, empati) og Barth (transaksjon og risiko) dukket direkte og indirekte opp i intervjuene med studentene. Dette viser både at teoriene er 
empirisk relevante, og at denne praksisopplæringa med gruppesamarbeid virket bevisstgjørende på studentene. Den ga dem anledning til å reflektere over hva det vil si å samarbeide, samtidig som de fikk trening i og erfaring med å samarbeide som framtidige lærere.

Dette har vært en studie av yrkesfaglærerstudenter i praksisopplæring. Vi tror at det vi har funnet ut her om samarbeid og lærerprofesjonalitet, ikke bare gjelder yrkesfaglærerstudenter, men alle lærerstudenter. Det ville være interessant med videre forskning på dette området.

\section{Om forfatterne}

Stein Rafoss er førstelektor emeritus i filosofi. Han studerte i Frankfurt am Main i 1967-1968, og hadde siden forskningsopphold ved universitetene i Frankfurt am Main og i Heidelberg. Han har arbeidet ved Universitetene i Oslo, Tromsø og Agder. Det er politisk filosofi, politisk økonomi, vitenskapsfilosofi og etikk som er hans forskningsinteresser. Har også undervist i videregående skole i flere år.

Hilde Witsø er førstelektor i pedagogikk ved Universitetet i Agder, Institutt for pedagogikk der hun arbeider som faglærer og forsker innen fagområdene generell didaktikk og yrkespedagogikk. Hennes forskningsinteresser er innen yrkesopplæring i skole, bedrift og universitet. Hun har tidligere vært lærer ved ulike institusjoner for barn og unge og har bred erfaring fra yrkesfaglig videregående opplæring. 


\section{Referanser}

Aspøy, T. M., Skinnarland, S. \& Tønder, A. H. (2017). Yrkesfaglærernes kompetanse. (Fafo-rapport 2017:11). Fafo.

Barth, F. (1994). Modeller av sosial organisasjon. I F. Barth, Manifestasjon og prosess (s. 31-46). Universitetsforlaget.

Collins, H. (2010). Tacit and explicit knowledge. University of Chicago.

Creswell J. W. \& Poth, C. N. (2009). Qualitative inquiry \& research design: Choosing among five approaches. Sage Publications.

Dale, E. L. (1989). Pedagogisk profesjonalitet: Om pedagogikkens identitet og anvendelse. Gyldendal.

Dale, E. L. (1993). Den profesjonelle skole: Med pedagogikken som grunnlag. Ad Notam Gyldendal.

Dale, E. L. (2001). Profesjonell kompetanse med ansvar for kvalitet. Læringslabben.

De Hei, M., Admiraal, W., Sjoer, E. \& Strijbos, J. W. (2018). Group learning activities and perceived learning outcomes. Studies in Higher Education, 43(12), 2354-2370.

Dreyfus, H. \& Dreyfus, S. (1986). Mind over machine: The power of human intuition and expertise in the era of the computer. Free Press.

Ertsås, T. I. \& Irgens, E. J. (2012). Teoriens betydning for profesjonell yrkesutøvelse. I M. B. Postholm (Red.), Lxreres laring og ledelse av profesjonsutvikling (s. 195-215). Tapir Akademisk Forlag.

Flyvbjerg, B. (1997) Rationalitet og magt: Bind I. Det konkretes videnskap. Akademisk forlag.

Grimen, H. \& Molander A. (2008). Profesjon og skjønn. I A. Molander \& L. I. Terum (Red.), Profesjonsstudier (s. 179-195). Universitetsforlaget.

Grimen, H. (1991). Taus kunnskap og organisasjonsstudier (Notat 91/28). LOS-senter.

Grimen, H. (2008). Profesjon og kunnskap. I A. Molander \& L. I. Terum (Red.), Profesjonsstudier (s. 71-85). Universitetsforlaget.

Hegel, G. W. F. (1999). Åndens fenomenologi. Pax.

Helleve, I., Ulvik, M. \& Smith, K. (2018). "Det handler om å finne sin egen form" Læreres profesjonelle handlingsrom - hvordan det blir forstått og utnyttet. Acta Didactica Norge, 12(1), Art. 1, 22 sider. https://doi.org/10.5617/adno.4794

Hiim, H. \& Hippe, E. (2009). Undervisningsplanlegging for yrkesfaglærere (3. utg.). Gyldendal Akademisk.

Hiim, H. (2010). Pedagogisk aksjonsforskning: Tilnærminger, eksempler og kunnskapsfilosofisk grunnlag. Gyldendal Akademisk.

Hiim, H. (2013). Praksisbasert yrkesutdanning: Hvordan utvikle relevant yrkesutdanning for elever og arbeidsliv? Gyldendal Akademisk. 
Hiim, H. (2020). Å vurdere yrkeskompetanse: Hva er yrkeskompetanse, og hvordan kan den vurderes? Nordic Journal of Vocational Education and Training, 10(3), 45-66. https://doi.org/10.3384/njvet.2242-458X.2010345

Honneth, A. (2008). Kamp om anerkjennelse. Pax.

Honneth, A. (2009). Mellom Aristoteles og Kant: Skisse til anerkjennelsens moral. Agora, 27(4), 159-177.

Jensen, A. R., Ringereide, H. O. \& Witsø, H. (2019). Den triadiske modellen: Planlegging, gjennomføring og vurdering av undervisning. Cappelen Damm Akademisk.

Johannesen, H. S. (2015). Cultural codes of technical and vocational teachers: A qualitative study of technical and vocational teachers' cultural codes. Teaching school-based learning at the Norwegian upper secondary level. [Doktorgradsavhandling, Universitetet i Oslo].

Johannesen, H. S. (2019). Miskjennelse av yrkesfaglig kulturell kapital i skolen. Norsk pedagogisk tidsskrift, 103(4), 277-287.

Johannessen, A., Tufte, P. A. \& Kristoffersen, L. (2004). Introduksjon til samfunnsvitenskapelig metode. Abstrakt forlag.

Johannessen, J. A. \& Olsen, B. (2008). Skoleledelse: Skolen som organisasjon. Fagbokforlaget.

Johannessen, L. E. F., Rafoss, T. W. \& Rasmussen, E. B. (2018). Hvordan bruke teori? Universitetsforlaget.

Karner, C. (2012). "Mein" Kompetenzprofil, Eine Forschungsreise in die eigene Kompetenzlandschaft. Trauner Verlag.

Kristiansen, A. (2014). Tillit og kommunikasjon i ulike samarbeidsprosesser. I H. H. Grelland, S. Botnen, A. Kristiansen, H. I. Sævareid \& D. G. Aasland, Samarbeidets filosofi (s. 137-157). Gyldendal akademisk.

Kunnskapsdepartementet. (1998). Lov om grunnskolen og den vidaregåande opplaringa. https:/ / lovdata.no/dokument/NL/lov/1998-07-17-61

Kunnskapsdepartementet. (2013). Forskrift om rammeplan for praktisk-pedagogisk utdanning for yrkesfag for trinn 8-13. https://lovdata.no/dokument/SF/forskrift/2013-03-18-289

Kunnskapsdepartementet. (2015). Strategi Yrkesfaglærerløftet - for fremtidens fagarbeidere.

Kunnskapsdepartementet. (2017a). Lærerutdanning 2025: Nasjonal strategi for kvalitet og samarbeid i lærerutdanningene.

Kunnskapsdepartementet. (2017b). Meld. St. 21 (2016-2017). Lærelyst - tidlig innsats og kvalitet $i$ skolen. https://www.regjeringen.no/no/dokumenter/meld.st.-21-20162017/id2544344/

Lave, J. \& Wenger, E. (1991). Situated learning: Legitimate peripheral participation. Cambridge University Press.

Lensjø, M. (2016). Læring og opplæring i rørleggerfaget: En etnografisk studie av fagog yrkesopplæring i opplæringskontor og på byggeplass. Institutt for Mennesker og Teknologi, Roskilde Universitet. 
Nielsen, K. \& Kvale, S. (1999). Mesterlære som aktuell læringsform. I K. Nielsen \& S. Kvale (Red.), Mesterlære: Læring som sosial praksis (s. 15-33). Gyldendal.

NOU 2008:18. (2008). Fagopplæring for framtida. Kunnskapsdepartementet.

NOU 2018:15. (2018). Kvalifisert, forberedt og motivert: Et kunnskapsgrunnlag om struktur og innhold i videregående opplæring. Kunnskapsdepartementet.

Polanyi, M. (1966). The tacit dimension. Doubleday \& Company.

Polanyi, M. (2000). Den tause dimensjonen: En introduksjon til taus kunnskap. Spartacus Forlag.

Universitetet i Agder (2020, 21. april) Praksis PPU-Y deltid 2. studieår https:/ / www.uia.no/om-uia/fakultet/avdeling-for-laererutdanning/utdanninger/ppu/praksis-ppu/praksis-ppu-y-deltid-2.-studieaar

Rafoss, Tore Witsø (2009) Tillitens årsaker: En komparativ undersøkelse av befolkningens og elitens institusjonelle tillit. [Mastergrad, Universitetet i Bergen].

Rafoss, T. W. \& Witsø, H. (2014). Fagenes krav og lovens bokstav: En kvantitativ undersøkelse av prøvenemndene på Agder. Norsk pedagogisk tidsskrift, 98(2), 78-92.

Schön, D. (1983). The reflective practitioner. Basic Books.

Stousland, H. \& Witsø, H. (2015). Er stasjonsopplæring i videregående skole en metode som er egnet til å støtte yrkesfageleven i vurdering av egen læring? Nordic Journal of Vocational Education and Training, 5(1), 1-16.

Strømfors, G. \& Edland-Gryt, M. (2013). Jeg visste ikke at jeg kunne så mye: Praksisrefleksjon på arbeidsplassen. Gyldendal.

Witsø, H. (1999). Lærling, læring, opplæringsboka: En kvalitativ studie av barne-og ungdomsarbeiderlærlingen og opplæringsboka. [Hovedfagsoppgave i barnehagepedagogikk, Høyskolen i Oslo].

Aarkrog, V. (2018). Teorier om læring anvendt i erhvervsuddannelsernes didaktik. Munksgaard.

Åsvoll, H. (2009). Teoretiske perspektiv på taus kunnskap: Muligheter for en taus pedagogikk. Tapir Akademisk Forlag. 